\title{
ALTERNATIVE VIEWS OF CASE RESEARCH IN INFORMATION SYSTEMS
}

\author{
Bill Dxolin \\ School of Managenent Studies, University of Waikato. Hamilton, New Zcaland \\ E-mail: wrd@waikato.ac.n.
}

\begin{abstract}
This paper discusses the differences between a positivist research philosophy and one which is increasingly emerging in is rescarch - an interpretive rescarch philosuphy, as they relate to case research, by cxamining selected case studies drawn from recent published IS case research. Each perspective places a different emphasis on case research. reflecting different ways of viewing reality and the pursuit of valid knowledge. This is an important realisation that can help us understand the debate that ofien arises over the nature and stature of case studies as a method for conducting research.
\end{abstract}

\section{INTRODUCTION}

Case studies are becoming increasingly popular in information systems (IS) research (Benbasat et al. 1987, Benbasat and Nault 1990). Boland and O'Leary (1991), in an editorial to Accounting, Management and Information Technologies, emphasise the fruitfulness of studying information technologies in the field. Such studies enable an examination of the interrelationship of information technologies with organisational activities and management practices. Frequently, however, discussions on the use of case studies in IS (e.g. Benbasat et al. 1987, Lee 1989) have used criteria derived from the application of "scientific method" to develop their methodology. Judging case studies by such standards unnecessarily limits their use in IS research.

Fundamental philosophical assumptions about the nature of reality, knowledge and human behaviour underlie any piece of research, and influence the researcher's notion of acceptable research methods (Chua 1986, Hopper and Powell 1985). Orlikowski and Baroudi (1991) suggest that a single set of philosophical assumptions, which they label positivist, dominates IS research. They argue that there are additional, alternative philosophies that can inform IS research, specifically interpretive and critical research traditions.

Assumptions about the nature of physical and social reality (ontology), together with assumptions about what constitutes valid knowledge (epistemology), influence what are considered acceptable methods for obtaining that knowledge (methodology). Differences in these underlying philosophical assumptions mean that case research enjoys a different status under different research traditions. Despite the obviousness of this argument, there is still misunderstanding over the nature and stature of case studies as a method for conducting research. Examples of the debate over the conduct and value of case studies can be seen in the IS literature (Benbasat et al. 1987, Dutton 1988, Benbasat $e t$ al. 1988) as well as in the management literature (Eisenhardt 1989, Dyer and Wilkins 1991, Eisenhardt 1991).

The aim of the paper is to illustrate the differences between a positivist research philosophy and one which is increasingly emerging in IS research - an interpretive research philosophy, as they relate to case research, by examining selected case studies drawn from recent published IS case research. The intention is to contribute an understanding of the differences in approaches to case research under these two research traditions, which may assist members of the Australasian IS community who are reading the product of case research or contemplating conducting case research themselves.

First, the philosophical assumptions underlying the positivist and interpretive research traditions are reviewed, and their implications for the conduct of case research are discussed. ${ }^{1}$ Second, case research is defined for the purposes of this study, and the process used to review recent IS case research is described. Research design characteristics of the case studies reviewed are then discussed, and the different purposes of selected case studies under positivist and interpretive research philosophies are examined.

1. For a fuller discussion of each research philosophy, its underlying assumptions and its application to IS research, the reader is directed to Orlikowski and Baroudi (1991). For reviews of the "scientific" approach to case study method in IS see Benbasat $e t$ al. (1987) and Lee (1989). For a recent discussion of the interpretive use of case studies in IS see Walsham (1993). For coverage of altemative research approaches in IS more generally, see Nissen et al. (1991). 


\section{POSITIVIST AND INTERPRETIVE CASE RESEARCH}

A positivist research philosophy presupposes a reality which exists independently of our knowledge of it. However, experience with this singular, tangible reality can result in knowing it fully, given enough time and sound investigative procedures. Individual studies may only be approximations, but eventually convergence will occur (Lincoln and Guba 1985).

A positivist research philosophy understands organisations as having a structure and reality beyond the actions of its members. This objective structure is capable of being discovered and measured using researcher-devised constructs. The validity and reliability of these identifying and measuring instruments is of particular concern, as is the passive, neutral role played by the researcher in the investigation. Large sample surveys and controlled experiments are primarily used, to deductively establish causal relationships and universal laws which form the basis of generalised knowledge, and from which patterns of behaviour can be predicted across a range of situations. The data revealed are assumed to be identifiable and exist independent of the method used to measure them. Importantly, participants in the research are required to express their experiences in terms of the researcher's constructs, facilitating replication in other settings (Orlikowski and Baroudi 1991).

Case research under a positivist research philosophy tends to be evaluated using criteria common to experimental and survey research (Dutton 1988). The concern is to conduct case studies in such a way so as to satisfy the standards of the natural science model of scientific research - controlled observations, controlled deductions, replicability and generalisability (Lee 1989). While acknowledging the complexity of organisational processes, researchers in this tradition tend to assign case studies a preliminary role in developing measurement constructs or as an exploratory tool for developing hypotheses for subsequent, more rigorous, investigation. Case studies are often viewed as particularly appropriate where research and theory are at their early, formative stages and lack a strong theoretical base (Benbasat et al. 1987). However, the use of case studies to build theory which is generalisable across settings has been proposed by authors such as Yin (1989) and Eisenhardt (1989). It involves the use of multiple cases to conduct cross-case comparisons under a replication logic analogous to scientific experiments (as opposed to the sampling logic behind survey research, for example).

An interpretive research philosophy asserts that reality and our knowledge of it are social products which cannot be understood independent of the social actors who construct and make sense of that reality. A shared social reality is produced and reproduced through ongoing social interaction, and can only be interpreted, rather than "discovered" (Orlikowski and Baroudi 1991). Actions cannot be understood without reference to their meaning (Chua 1986):

Through this process of continuous social interaction, meanings and norms become objectively (intersubjectively) real. They form a comprehensive and given social reality which confronts the individual in a manner analogous to the natural world (pp. 613-614).

Of course, constructed realities are often related to tangible entities, and while constructions differ between different individuals, they are often given a similar, agreed definition which constitutes a partial description of the entity. An information system can have physical components in the form of hardware and data communication cables. Nevertheless, an information system is understood (constructed) differently by different individuals and is given meaning by the shared understanding of such phenomena which arises out of social interaction.

Events, persons, objects are indeed tangible entities. The meanings and wholeness derived from or ascribed to these tangible phenomena in order to make sense of them, organize them, or reorganize a belief system, however, are constructed realities (Lincoln and Guba 1985, p. 84).

The interpretive tradition encourages a less strongly structured approach to the case research, favouring ethnographic techniques and participant observation as principal modes of data collection and emphasising the perceptions and explanations of participants in the organisation studied. Such research is experiential and interpretive (Ansari 1991). The researcher approaches the organisation studied with less preconceptions and prior categories. The primary purpose is to offer an interpretation of and for human conduct.

\section{A REVIEW OF RECENT IS CASE RESEARCH}

In order to gather a rich set of IS case research, the publications of four journals between 1989 and 1993 were examined. The intention was to examine examples of case research in the IS area, rather than attempt an exhaustive survey of published IS research. MIS Quarterly (MISQ) and Information and Management (I\&M) are core IS journals which publish the majority of IS empirical research (Cheon et al. 1993). Information Systems Research (ISR), is relatively new, but is already well regarded. The fourth journal, Accounting, Management and Information Technologies (AMT), is also new and was selected because of its editorial commitment to publishing field 
research. It was first published in 1991 and publishes research concerning information systems and organisattional practices.

Table 1 shows that of the journals surveyed, the primary publishing outlets for IS case research were MIS Quarterly and Information and Management. Of course, the journals vary considerably in the number of years they have been in existence and the number of articles published in them per year.

Table 1: Journals reviewed for the period 1989-1993

\begin{tabular}{||lcccc||}
\hline Joumal & $\begin{array}{c}\text { Publication } \\
\text { period }\end{array}$ & $\begin{array}{c}\text { Number of IS case } \\
\text { research articles }\end{array}$ & $\begin{array}{c}\text { Percentage of total } \\
\text { sample }\end{array}$ & $\begin{array}{c}\text { Percentage of total } \\
\text { joumal output }\end{array}$ \\
\hline MISQ & $1989-1993$ & 20 & $40 \%$ & $16 \%$ \\
I\&M & $1989-1993$ & 18 & $36 \%$ & $6 \%$ \\
ISR' & $1990-1993$ & 6 & $12 \%$ & $10 \%$ \\
AMIT & $1991-1993$ & 6 & $100 \%$ & $18 \%$ \\
Total & 50 & & \\
\hline
\end{tabular}

Two standard identifying characteristics were used to distinguish case research from other types of research. First, the researcher has direct contact with organisational participants, and these contacts provide the primary source of research data. Second, the research focuses on actual organisational tasks or processes (Ferreira and Merchant 1992).

Case research is the study of social practices in the field of activity in which they take place (Scapens 1990). The implication here is that the phenomenon under study is investigated within its "real-life context" (Yin 1989). Experiments and surveys are thus excluded from this definition, since an experiment divorces the phenomenon from its context, and surveys are limited in their ability to investigate contexi (Yin 1989). This close involvement with the organisation means that interviews and direct observations of activities tend to be the primary means of data collection in case research.

Fifty studies published since 1989 met the above criteria for case research. Where studies involved multiple data collection methods, the decision to include or exclude them in the review was, admittedly, a subjective one. For example, studies where a survey was the primary method of data collection, and in which interviews were used only for instrument validation or in which follow-up interviews and site visits were used only to clarify results, were excluded. Studies where interviews were used only to administer a structured survey instrument were also excluded. The extent of organisational contacts and the importance the authors placed on the results they gained from them were used as criteria for making the decision.

The focus was on empirical research, defined by Benbasat and Nault (1990) as "research that uses qualitative or quantitative data as a basis for the investigation of research questions" (p. 211). Cases where the motivation was simply to describe the development or implementation of a particular information system, in the absence of an explicit research objective, were excluded from the survey. These "application descriptions" (Benbasat et al. 1987) frequently conclude with a list of lessons or recommendations for the development or implementation of similar systems. Cases based on publicly available, secondary data were also excluded.

Table 2 provides characteristics of selected case studies referred to in the subsequent discussion. The table is intended as a guide for readers who wish to examine in more detail IS case studies which illustrate the range of approaches to case research recently utilised under positivist and interpretive research philosophies. 
Table 2: Recent examples of IS case research

\begin{tabular}{|c|c|c|c|c|}
\hline Study & Topic & Site(s) & Data Sources & Findings \\
\hline \multicolumn{5}{|l|}{ Positivist } \\
\hline Alavi (1993) & $\begin{array}{l}\text { Evaluation of } \\
\text { electronic meeting } \\
\text { system }\end{array}$ & $\begin{array}{l}1 \quad \text { company } \\
\text { headquarters } \\
\text { (US) }\end{array}$ & $\begin{array}{l}\text { Questionnaire } \\
\text { Interviews } \\
\text { Observation }\end{array}$ & $\begin{array}{l}\text { Extends prior laboratory } \\
\text { research to an } \\
\text { organisational setting }\end{array}$ \\
\hline Aydin and & Predicting attitudes & 1 university & Questionnaires & \\
\hline Rice (1991) & $\begin{array}{l}\text { towards a medical } \\
\text { IS }\end{array}$ & $\begin{array}{l}\text { student health } \\
\text { service }\end{array}$ & $\begin{array}{l}\text { Structured interviews } \\
\text { Observation }\end{array}$ & $\begin{array}{l}\text { Adds new variables to } \\
\text { prior } \\
\text { research }\end{array}$ \\
\hline $\begin{array}{l}\text { Blanton et al. } \\
\text { (1992) }\end{array}$ & IT organisation & 2 banks (US) & $\begin{array}{l}\text { Document review } \\
\text { Structured interviews } \\
\text { Questionnaire }\end{array}$ & $\begin{array}{l}\text { Exploratory contribution } \\
\text { to a contingency theory of } \\
\text { IT organisation }\end{array}$ \\
\hline $\begin{array}{l}\text { Doll and Doll } \\
\text { (1992) }\end{array}$ & IS downsizing & $\begin{array}{l}1 \text { distribution } \\
\text { company (US) }\end{array}$ & $\begin{array}{l}\text { Structured interviews } \\
\text { Document review }\end{array}$ & $\begin{array}{l}\text { Exploratory description of } \\
\text { a recent phenomenon }\end{array}$ \\
\hline Earl (1993) & $\begin{array}{l}\text { Strategic } \\
\text { planning }\end{array}$ & $\begin{array}{l}21 \text { companies } \\
\text { (UK) }\end{array}$ & Structured interviews & $\begin{array}{l}\text { Exploratory construction } \\
\text { of a SISP taxonomy }\end{array}$ \\
\hline $\begin{array}{l}\text { Feeny et al. } \\
\text { (1992) }\end{array}$ & $\begin{array}{l}\mathrm{CEO} / \mathrm{CIO} \\
\text { relationship }\end{array}$ & $\begin{array}{l}14 \mathrm{CEO} / \mathrm{ClO} \\
\text { pairs (UK) }\end{array}$ & Structured interviews & $\begin{array}{l}\text { Exploratory insights into } \\
\text { CEO/CIO relationships }\end{array}$ \\
\hline $\begin{array}{l}\text { Lederer and } \\
\text { Mendelow } \\
\text { (1990) }\end{array}$ & $\begin{array}{l}\text { Impact of } \\
\text { environment on IS } \\
\text { management }\end{array}$ & 20 IS executives & Structured interviews & $\begin{array}{l}\text { Exploratory groundwork } \\
\text { for testable hypotheses }\end{array}$ \\
\hline $\begin{array}{l}\text { Reich and } \\
\text { Benbasat } \\
(1990)\end{array}$ & $\begin{array}{l}\text { Factors influencing } \\
\text { success of } \\
\text { customer-oriented } \\
\text { strategic systems }\end{array}$ & $\begin{array}{l}11 \text { systems in } \\
\quad 9 \\
\text { companies } \\
\text { (Canada) }\end{array}$ & $\begin{array}{l}\text { Structured interviews } \\
\text { Document review }\end{array}$ & $\begin{array}{l}\text { Identifies factors for } \\
\text { hypothesis generation; } \\
\text { develops a model of } \\
\text { cOSS success }\end{array}$ \\
\hline Zack (1993) & $\begin{array}{l}\text { Interactivity and } \\
\text { communication } \\
\text { mode choice }\end{array}$ & $\begin{array}{l}2 \quad \text { daily } \\
\text { newspapers }\end{array}$ & $\begin{array}{l}\text { Interviews } \\
\text { Observation } \\
\text { Email capture } \\
\text { Questionnaire }\end{array}$ & $\begin{array}{l}\text { Exploratory study; } \\
\text { formulates propositions } \\
\text { for future research }\end{array}$ \\
\hline \multicolumn{5}{|l|}{ Interpretive } \\
\hline $\begin{array}{l}\text { Bloomfield } \\
\text { et al. (1992) }\end{array}$ & $\begin{array}{l}\text { Construction } \\
\text { hospital IS }\end{array}$ & $\begin{array}{l}3 \quad \text { public } \\
\text { hospitals (UK) }\end{array}$ & $\begin{array}{l}\text { Interviews } \\
\text { Document review }\end{array}$ & $\begin{array}{lr}\text { Explains } & \text { interpretive } \\
\text { flexibility } & \text { surrounding }\end{array}$ \\
\hline & & & Observation & $\begin{array}{l}\text { implementation of } \\
\text { resource management } \\
\text { systems }\end{array}$ \\
\hline $\begin{array}{l}\text { Hirschheim } \\
\text { and Newman } \\
\text { (1991) }\end{array}$ & $\begin{array}{l}\text { Symbolism and IS } \\
\text { development }\end{array}$ & $\begin{array}{l}4 \text { organisations } \\
\text { (US, Canada, } \\
\text { UK) }\end{array}$ & $\begin{array}{l}\text { Nondirective } \\
\text { interviews }\end{array}$ & $\begin{array}{l}\text { Uses symbolism to better } \\
\text { understand } \\
\text { development }\end{array}$ \\
\hline $\begin{array}{l}\text { Orlikowski } \\
\text { (1991) }\end{array}$ & $\begin{array}{l}\text { IT } \quad \text { and } \\
\text { organisational } \\
\text { control }\end{array}$ & $\begin{array}{l}1 \quad \text { software } \\
\text { consulting firm }\end{array}$ & $\begin{array}{l}\text { Observation } \\
\text { Unstructured and } \\
\text { semi-structured } \\
\text { interviews } \\
\text { Document review } \\
\text { Social contact }\end{array}$ & $\begin{array}{l}\text { Provides an understanding } \\
\text { of control and deployment } \\
\text { of IT in organisations }\end{array}$ \\
\hline
\end{tabular}




\begin{tabular}{|lllll||}
\hline $\begin{array}{l}\text { Wastell and } \\
\text { Newman }\end{array}$ & $\begin{array}{l}\text { Behavioural } \\
\text { dynamics of IS }\end{array}$ & 2 universities & Interviews & Uses a stress model to \\
(1993) & development & & gain insights into the \\
& & & $\begin{array}{l}\text { systems development } \\
\text { process }\end{array}$ \\
\hline
\end{tabular}

\section{RESEARCH DESIGN}

Most of the studies reviewed were descriptive in that the authors described organisational contexts and practices in their presentation of their research. However, most researchers went beyond just describing the case or cases they studied, and attempted to contribute to theory in some way. Most commonly they described their observations and then reflected on their observations' theoretical significance (Ferreira and Merchant 1992). The majority of the studies examined (about $80 \%$ ) fell within the mainstream, positivist orientation that dominates IS research (Orlikowski and Baroudi 1991). ${ }^{2}$ That is not to say that they were necessarily good examples of positivist epistemology. The descriptive approach of many of the studies lacked strong methodological development of any kind.

Case research designs can be categorised as case studies, multiple case designs and case surveys (Den Hertog and Wielinga 1992). Single case studies allow in-depth analysis of one setting with regard to a large number of aspects, allowing a broad and detailed analysis of organisational dynamics, and the production of the rich descriptions favoured by interpretive researchers. A multiple case design usually sacrifices detail and richness of description for the opportunity to make comparisons across several settings. Multiple case designs are necessary for generating generalisable theory under the replication logic of positivist case research (Eisenhardt 1989, Yin 1989). Case surveys are capable of generating information from a large number of settings, but are usually restricted to a small number of narrowly defined and often quantitatively expressed variables.

The research designs of the studies reviewed are shown in Table 3. Multiple case designs were mainly used to increase the diversity of settings examined, and only occasionally for cross-case comparisons (e.g. Blanton et al. 1992). The relatively large proportion of multiple case designs among the interpretive studies is interesting, although the median number of cases was two, which is lower than the median of four cases for the positivist multiple case designs. Often, the interpretive studies used more than one setting without an apparent loss of depth. For example, Bloomfield et al. (1992) conducted field work in three different sites over a three year period. The case surveys in this review typically interviewed a single individual in each organisation using very structured interview techniques, and gave comparatively less information on organisational contexts.

Table 3: Research designs

\begin{tabular}{|lccc||}
\hline & Positivist & Interpretive & Total \\
\hline Case study & 13 & 5 & 18 \\
Multiple case design & 17 & 6 & 23 \\
Case survey & 9 & 0 & 9 \\
Total & 39 & 11 & 50 \\
& & & \\
\hline
\end{tabular}

As expected, interviews were the primary method of data collection in the studies reviewed. However, the interviews varied widely in terms of both their structure and their extent. Unstructured, semi-structured and structured interviews were all used. Unfortunately, many authors failed to describe what they meant by these terms. Some interviews were relatively unstructured or "nondirective", but with guidance over topics to be discussed:

A nondirective interviewing technique was used, as this allowed the respondents to express their own views in their own words rather than force their experience into predetermined categories. However, the interviews focussed on certain topics which are important in the literature (Hirschheim and Newman 1991, p. 42).

2. In their review of IS research literature published between 1983 and 1988, Orlikowski and Baroudi (1991) found that a dominant set of assumptions reflecting a positivist perspective informs IS research. They found only 5 interpretive studies in the 155 research articles they surveyed. 
Other interviews were more structured, using a list of open-ended questions as an interview protocol. For example, Lederer and Mendelow (1990), in their study of the impact of environment on the management of IS, structured their interviews by asking a similar set of three questions about each of five dimensions of the environment. The most structured interviews solicited quantitative responses as well as qualitative ones, often using Likert-type scales. These very structured interviews were frequently a feature of the case surveys (e.g. Earl 1993, Feeny et al. 1992).

Less than a third of the studies fully disclosed the extent of their interviewing. The practice was more typical of positivist oriented studies, presumably in an effort to provide sufficient information for readers to judge the adequacy of the time spent in the organisation (Ferreira and Merchant 1992). The interpretive studies tended to rely on the richness of their descriptions to convince the reader of their validity. While there were extremes among the studies that provided information, 20-30 interviews of 1-2 hours duration was typical.

Other data collection methods were used to supplement and corroborate the evidence obtained from interviewing. A number of studies reported examining archival data and company documentation. For example, Doll and Doll (1992) examined 78 items which included the IS strategic plan, budgets, management correspondence, organisational charts, consultant reports and system architecture diagrams. Other reported sources of documentary evidence included annual reports, job descriptions, minutes of meetings and project documentation.

Several studies directly observed IS activity, including electronic meeting systems sessions (e.g. Alavi 1993) and project meetings (e.g. Bloomfield et al. 1992). Sometimes observation had a primary role in the research. Zack (1993) attended 16 meetings and spent 140 hours observing the publishing process in 2 daily newspapers.

Some studies used a multiple phase approach to combine field interviews with questionnaires. Commonly, the quantitative and qualitative results were used in a confirmatory way as a form of triangulation, but in other instances the two types of evidence complemented each other (Alavi 1993) or a comparison between them yielded additional information (Aydin and Rice 1991).

\section{RESEARCH PURPOSE}

The most common purpose given in the positivist studies was exploratory. Usually the motivation was simply to describe and explore the research subject, providing useful insights or identifying common factors. Sometimes the study focused on a recent problem or issue without an established literature or on a unique situation. For example, in the study by Doll and Doll (1992), the objective was to describe and explore a phenomenon, IS downsizing, which is not well understood.

Some of the exploratory studies went a step further and generated formal hypotheses or propositions from the results of their research. This motivation seemed to arise out of the positivist concern for "scientific" testing of theory, and was demonstrated by Feeny et al. (1992):

Given the small size of the sample, it is inappropriate to formally test the research propositions implied by the model ... The study was instead intended to build insights using the depth rather than breadth of the data. This, we felt, would lead to stronger propositions that could be tested by subsequent work (p. 438).

Lederer and Mendelow (1990) commented similarly on the contribution made by their study of the impact of environment on IS management:

[T] he paper contributes to IS theory and research by providing the groundwork for some testable hypotheses ... Future research should test the model ... using a larger sample and more objective (i.e., survey-based) data (p. 219). And again, Zack (1993):

The results provide a foundation on which to build more focused and controlled (e.g., social survey or behavioral laboratory) studies of communication context and its relationship to communication mode characteristics and communication effectiveness (p. 235).

In many respects, the study by Blanton et al. (1992) is a typical example of a positivist treatment of case research. Because prior research on the issues they wished to study was limited, the authors selected a case-oriented methodology. Their research was exploratory, suggesting certain attributes of the relationship between IT organisational structure and IT support effectiveness, and generating three propositions which required further empirical studies to either confirm or deny them. The limitations in applying these propositions were clearly stated; in this case, only to organisations with similar external environments and competing in industries with similar technological sophistication. Validity was explicitly addressed through the use of multiple sources of evidence and 
reviews by key informants. A case study protocol was developed, and an expert panel used to analyse the case descriptions, in order to improve reliability by reducing researcher bias. ${ }^{3}$

A few studies went a step further and attempted to develop theory in some way. Some found evidence to support theoretical propositions. Others attempted to extend prior theory to a new setting. For example, Alavi's (1993) assessment of the effectiveness of electronic meeting systems in a field setting was motivated by the limitations that the laboratory setting of previous studies imposed on their generalisability to more complex settings. Sometimes, the study introduced new variables to an existing theoretical base, such as when Aydin and Rice (1991) suggested that membership in occupational and social worlds also influences individual attitudes towards information systems. Other studies constructed theoretical frameworks or models. For example, Earl (1993) identified a taxonomy of five approaches to strategic IS planning using descriptive classification and inductive interpretation of organisational experiences. Reich and Benbasat (1990) proposed a multi-stage model of customer-oriented strategic systems success to guide future research.

The studies reviewed which had their primary motivation in interpretation attempted to describe, interpret and understand IS phenomena, often utilising an alternative perspective to the technical or "rational" view of the mainstream, positivist tradition. For example, Hirschheim and Newman (1991) challenged the orthodox view that systems development is a normative process reflecting conventional economic reality. As an altemative basis for understanding the actual practice of systems development, they used the concept of symbolism to interpret the social actions and behaviour of developers and users in the development process.

Many of these interpretive studies attempted to convince the reader of the perceived limitations of the orthodox approach and that an alternative perspective could provide new insights into IS problems. For example, Wastell and Newman (1993) examined the behavioural dynamics of systems development, utilising a stress perspective, and concluded that:

The rational-technical view of systems development presented in most textbooks is a caricature. Information system development is a complex, protean, social phenomenon; conflict is endemic ... Simple prescriptions such as "get top management support" or the pious call for user involvement grotesquely oversimplify the exacting realities of actual systems work (pp. 142-143).

The study by Orlikowski (1991) which described how the deployment of an information technology affected production workers is a useful illustration of the interpretive approach to case research, one which she terms "organizational ethnography". Her study employed ethnographic techniques such as observation of participants, researcher interaction with the information technology, documentation review, social contact, unstructured and semi-structured interviews, over an eight month period. 4 She used a theoretical framework to focus her questions and observations, but used no structured instrumentation or statistical analysis of her data.

The aim was to understand the implications of the information technology through understanding the norms and meanings that the workers shared around their work, how they interacted among themselves and with the information technology, and how these meanings and experiences changed with the deployment of the information technology. Her study highlighted the tendency for information technology to be implemented so as to reflect existing forms of knowledge, legitimacy and authority, thus supporting the organisational status quo.

\section{DISCUSSION}

By comparing and contrasting IS case research conducted in an interpretive tradition with that of the dominant positivist research philosophy, I have attempted to illustrate the different treatment of case research by researchers utilising different philosophical assumptions. The differences in approach are fundamental. The positivist assumption of an objective, measurable reality, with fixed causal relationships, encourages the use of more structured interviews to collect data for relevant variables. In this way inferences about a phenomenon can be generalised from the study setting to a population. An objective reality also implies that there is one correct answer or truth, so when conflicting answers from the multiple individuals interviewed arose in the study by Reich and Benbasat (1990), the interviewer "resolved" them during the interview or made a judgement about the final answer based on the individual's perceived reliability.

3. Other validation approaches used in some of the studies included seeking support for the research findings by comparing them to prior research in IS and other management disciplines, and using multiple interviewers, who compared and cross-checked their notes after each session to increase control.

4. Participant observation, although not utilised by Orlikowski, would have assisted in weighing intentions and impressions against actual behaviour (Orlikowski and Baroudi 199i). 
Since in the socially-constructed, subjective reality of the interpretive tradition no one perspective is more valid than another, multiple perspectives are actively sought by interviewing participants who span the organisation's hierarchic levels (e.g. Orlikowski 1991) or different levels in the system development process (e.g. Hirschheim and Newman 1991). Less structured interviewing techniques are used to encourage the participants to express and develop their own views unrestricted by the interviewer's preconceptions. Conflict and tension in research evidence are exploited to reveal differing aspects of the phenomenon (Covaleski and Dirsmith 1990).

Interpretive research does not seek to generalise in the statistical sense (Ansari 1991). Instead, a deeper understanding of the phenomenon is sought, which can then be used to inform other settings (Orlikowski and Baroudi 1991). From an interpretive position, the validity of doing so relies on the plausibility of the logical reasoning used in describing the results and in drawing conclusions from them (Walsham 1993).

The positivist concern with objectivity is reflected in the comment of Benbasat $e t$ al. (1987) on the attempts of some researchers to generate explanations of their observations:

While on the positive side the explanations were grounded in observed facts, our concern is that these facts were filtered through the subjective lenses of the investigators (p. 378).

If we acknowledge the subjective nature of all research, a positivist epistemology itself becomes a subjectively selected "lens" through which the world is viewed. Researchers need to understand the implications of their research perspective and be open to the possibility of other research traditions (Orlikowski and Baroudi 1991). This implies that we need to acknowledge the assumptions, beliefs and value judgements that we use in addressing research questions and in making knowledge claims (Humphrey and Scapens 1992).

Methodologies informed by a positivist research philosophy tend to treat case research as an exploratory tool for developing hypotheses in the construction of "scientific" theory. By contrast, interpretive methodologies give a more central role to case research, utilising case studies to obtain a deeper understanding of the phenomenon and of the meaning of human behaviour. Each perspective places a different emphasis on case research, reflecting different ways of viewing reality and the pursuit of valid knowledge. This is an important realisation that can help us understand the debate that often arises over the use of case studies and appropriate criteria for evaluating them.

Case studies of organisational aspects of IS have a broader role to play than merely as "necessary precursors to more elaborate, large sample hypothesis testing" (Humphrey and Scapens 1992, p. 1). The contextual complexities involved in studying information systems in organisations and the need to interpret IS activities in the context of other organisational activity demand a depth of understanding which can only be achieved through the close involvement of the researcher with the organisation of interest. By conducting research in this way, the researcher is more likely to find a satisfactory basis for understanding and providing meaning to the research subject.

\section{REFERENCES}

Alavi, M. (1993) An Assessment of Electronic Meeting Systems in a Corporate Setting, Information and Management, Vol 25(4), pp 175-182.

Ansari, S.L. (1991) Field Research in Management Accounting: The Ethnographic Tradition , Paper presented at the Conference on Field Research Skills in Management Accounting (American Accounting ssociation), Boulder, Colorado, March 1991.

Aydin, C.E. \& Rice, R.E. (1991) Social Worlds, Individual Differences, and Implementation: Predicting Attitudes Toward a Medical Information System , Information and Management, Vol 20(2), pp 119-136.

Benbasat, I., Goldstein, D.K. \& Mead, M. (1987) The Case Research Strategy in Studies of Information Systems, MIS Quarterly, Vol 11(3), pp 369-386.

Benbasat, I., Goldstein, D.K. \& Mead, M. (1987) Letter to the Editor, MIS Quarterly, Vol 12(4), p 522.

Benbasat, I. \& Nault, B.R. (1990) An Evaluation of Empirical Research in Managerial Support Systems, Decision Support Systems, Vol 6(3), pp 203-226.

Blanton, J.E., Watson, H.J. \& Moody, J. (1992) Toward a Better Understanding of Information Technology Organization: A Comparative Case Study , MIS Quarterly, Vol 16(4), pp 531-555.

Bloomfield, B.P., Coombs, R., Cooper, D.J. \& Rea, D. (1992) Machines and Manoeuvres: Responsibility Accounting and the Construction of Hospital Information Systems, Accounting, Management and Information Technologies, Vol 2(4), pp 197-219.

Boland, R.J., Jr. \& O'Leary, T. (1991) Technologies of Inscribing and Organizing: Emerging Research Agendas , Accounting, Management and Information Technologies, Vol 1(1), pp 1-7.

Cheon, M.J., Grover, V. \& Sabherwal, R. (1993) The Evolution of Empirical Research in IS: A Study in IS Maturity, Information and Management, Vol 24(3), pp 107-119.

Chua, W.F. (1986) Radical Developments in Accounting Thought, The Accounting Review, Vol 61(4), pp 601632. 
Covaleski, M.A. \& Dirsmith, M.W. (1990) Dialectic Tension, Double Reflexivity and the Everyday Accounting Researcher: On Using Qualitative Methods, Accounting, Organizations and Society, Vol 15(6), pp 543573.

Den Hertog, F. \& Wielinga, C. (1992) Control Systems in Dissonance: The Computer as an Ink Blot , Accounting, Organizations and Society, Vol 17(2), pp 103-127.

Doll, W.J. \& Doll, M.W. (1992) Downsizing at CBS/FOX Video, Information and Management, Vol 23(3), pp 123-139.

Dutton, W.H. (1988) Letter to the Editor, MIS Quarterly, Vol 12(4), p 521.

Dyer, W.G., Jr. \& Wilkins, A.L. (1991) Better Stories, Not Better Constructs, to Generate Better Theory: A Rejoinder to Eisenhardt, Academy of Management Review, Vol 16(3), pp 613-619.

Earl, M.J. (1993) Experiences in Strategic Information Systems Planning, MIS Quarterly, Vol 17(1), pp 1-24.

Eisenhardt, K.M. (1989) Building Theories From Case Study Research, Academy of Management Review, Vol 14(4), pp 532-550.

Eisenhardt, K.M. (1991) Better Stories and Better Constructs: The Case for Rigor and Comparative Logic , Academy of Management Review, Vol 16(3). pp 620-627.

Feeny, D.F., Edwards, B.R. \& Simpson K.M. (1992) Understanding the CEO/CIO Relationship, MIS Quarterly, Vol 16(4), pp 435-448.

Ferreira, L.D. \& Merchant, K.A. (1992) Field Research in Management Accounting and Control: A Review and Evaluation, Accounting Auditing and Accountability Journal, Vol 5(4), pp 3-34.

Hirschheim, R. \& Newman, M. (1991) Symbolism and Information Systems Development: Myth, Metaphor and Magic , Information Systems Research, Vol 2(1), pp 29-62.

Hopper, T. \& Powell, A. (1985) Making Sense of Research into the Organizational and Social Aspects of Management Accounting: A Review of its Underlying Assumptions , Journal of Management Studies, Vol 22(5), pp 429-465.

Humphrey, C. \& Scapens, R. (1992) Theories and Case Studies: Limitation or Liberation, Accounting and Finance Working Paper 92/4, Manchester: University of Manchester.

Lederer, A.L. \& Mendelow, A.L. (1990) The Impact of the Environment on the Management of Information Systems, Information Systems Research, Vol 1(2), pp 205-222.

Lee, A.S. (1989) A Scientific Methodology for MIS Case Studies, MIS Quarterly, Vol 13(1), pp 33-50.

Lincoln, Y.S. \& Guba, E.G. (1985) Naturalistic Inquiry, Beverly Hills: Sage Publications.

Nissen, H-E., Klein, H.K. \& Hirschheim, R. (1991) Information Systems Research: Contemporary Approaches \& Emergent Traditions, Amsterdam: North-Holland.

Orlikowski, W.J. (1991) Integrated Information Environment or Matrix of Control? The Contradictory Implications of Information Technology, Accounting, Management and Information Technologies, Vol 1(1), pp 9-42.

Orlikowski, W.J. \& Baroudi, J.J. (1991) Studying Information Technology in Organizations: Research Approaches and Assumptions, Information Systems Research, Vol 2(1), pp 1-28.

Reich, B.H. \& Benbasat, I. (1990) An Empirical Investigation of Factors Influencing the Success of CustomerOrientated Strategic Systems , Information Systems Research, Vol 1(3), pp 325-347.

Scapens, R.W. (1990) Researching Management Accounting Practice: The Role of Case Study Methods, British Accounting Review, Vol 22(3), pp 259-281.

Walsham, G. (1993) Interpreting Information Systems in Organizations, Chichester: John Wiley \& Sons.

Wastell, D. \& Newman, M. (1993) The Behavioral Dynamics Of Information System Development: A Stress Perspective, Accounting, Management and Information Technologies, Vol 3(2), pp 121-148.

Yin, R.K. (1989) Case Study Research: Design and Methods, Rev. ed., Newbury Park, California: Sage Publications.

Zack, M.H. (1993) Interactivity and Communication Mode Choice in Ongoing Management Groups , Information Systems Research, Vol 4(3), pp 207-239. 